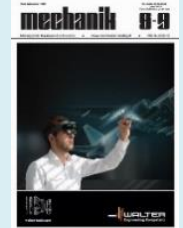

\title{
Analysis of forces and vibrations during milling of a metal-ceramic composite
}

\author{
Analiza sił oraz drgań podczas frezowania \\ kompozytu metalowo-ceramicznego
}

\author{
NATALIA ZNOJKIEWICZ \\ MAREK MADAJEWSKI \\ PAWEK TWARDOWSKI \\ SZYMON WOJCIECHOWSKI *
}

The article [3] presents the energy-based force model, developed for orthogonal cutting of MMC composites. The results showed compatibility between the predicted and measured cutting forces. The proposed model is based on the quantification of various energy inputs used during the cutting process [3].

In turn, the author of the work [8] proposed an exact model of cutting force applied to finishing milling with a ball end milling cutter. In addition to forces, the analysis of mechanical vibrations seems to be an important aspect. The work [4] shows an experimentally tested system to demonstrate the reduction of dynamic force as a result of vibration. Extensive testing has been carried out to validate system performance in terms of practical performance parameters such as improving surface finish and increasing tool durability.

The literature review shows that little research on the machining of $\mathrm{MMC}$ composites focuses on the analysis of dynamics during precision milling. Therefore, in this work, the components of total force and vibrations were evaluated, taking into account statistical measures and spectral analyzes of the signal.

\section{Aim, scope and methodology of research}

The purpose of the work was the analysis of forces and vibrations during milling of a metal-ceramic composite for various milling parameters.

The work material was an aluminum-ceramic composite F3S.10S by Duralcan with a matrix of aluminum reinforced with SiC particles. The most useful features of these composites are their high strength, stiffness and abrasion resistance.

The method of fixing the workpiece material is shown in fig. 1. The tests were carried out on the DECKEL MAHO three-axis milling center model DMC 70V Hi-Dyn with a maximum rotational speed $n=30,000 \mathrm{rpm}$.

The change of forces and vibrations was measured depending on the speed and feed rate, and their values used during milling are shown in the tab. I and tab. II.

As cutting tools, two monolithic end mills (tab. III) were mounted in a shrink-fit holder. The measurement of the components of the total force was made using a threecomponent dynamometer platform connected to the load amplifiers, an analog-digital converter and a PC equipped

\footnotetext{
* Mgr inż. Natalia Znojkiewicz (natalia.w.znojkiewicz@doctorate.put.poznan.pl), mgr inż. Marek Madajewski (marek.w.madajewski@doctorate.put.poznan.pl), dr hab. inż. Paweł Twardowski (pawel.twardowski@put.poznan.pl),dr inż. Szymon Wojciechowsk (szymon.wojciechowski@put.poznan.pl) - Politechnika Poznańska
} 
with a program for acquisition and overweighting data. The vibration was measured with a three-component piezoelectric accelerator attached to the workpiece. The vibration measurement station is equipped with a vibration sensor, a Brüel \& Kjær charge amplifier and a PC computer.

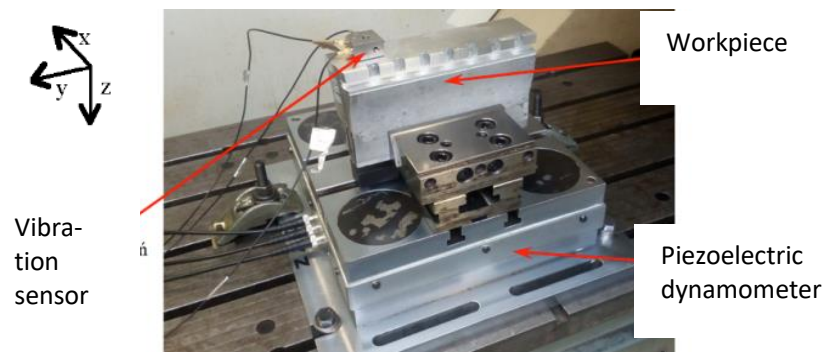

Fig. 1. Way of fixing the workpiece

TABLE I. Parameters adopted during milling at a constant feed per tooth $f=0.1 \mathrm{~mm} / \mathrm{rev}$

\begin{tabular}{||c|c|c|c||}
\hline $\begin{array}{l}\text { PCD } \\
\text { CBN }\end{array}$ & $v_{c}, \mathrm{~m} / \mathrm{min}$ & $n$, obr/min & $v_{\mathrm{f}}, \mathrm{mm} / \mathrm{min}$ \\
\hline 1 & 50 & 1591 & 159 \\
\hline 2 & 100 & 3182 & 318 \\
\hline 3 & 200 & 6364 & 636 \\
\hline 4 & 300 & 9546 & 955 \\
\hline 5 & 400 & 12728 & 1273 \\
\hline 6 & 500 & 15910 & 1591 \\
\hline 7 & 600 & 19093 & 1909 \\
\hline 8 & 700 & 22275 & 2227 \\
\hline
\end{tabular}

TABLE II. Parameters adopted during milling at constant cutting speed $v_{\mathrm{c}}=500 \mathrm{~m} / \mathrm{min}$

\begin{tabular}{||c|c|c|c||}
\hline $\begin{array}{c}\mathrm{PCD} \\
\mathrm{CBN}\end{array}$ & $f, \mathrm{~mm} / \mathrm{obr}$ & $f_{\mathrm{z}, \mathrm{mm} / \mathrm{ostrze}}$ & $v_{\mathrm{t}}, \mathrm{mm} / \mathrm{min}$ \\
\hline 1 & 0,01 & 0,0049 & 159 \\
\hline 2 & 0,03 & 0,015 & 477 \\
\hline 3 & 0,06 & 0,03 & 955 \\
\hline 4 & 0,09 & 0,045 & 1432 \\
\hline 5 & 0,12 & 0,06 & 1910 \\
\hline 6 & 0,18 & 0,09 & 2865 \\
\hline 7 & 0,30 & 0,15 & 4775 \\
\hline 8 & 0,50 & 0,25 & 7958 \\
\hline
\end{tabular}

\section{TABLE III. Applied cutters}

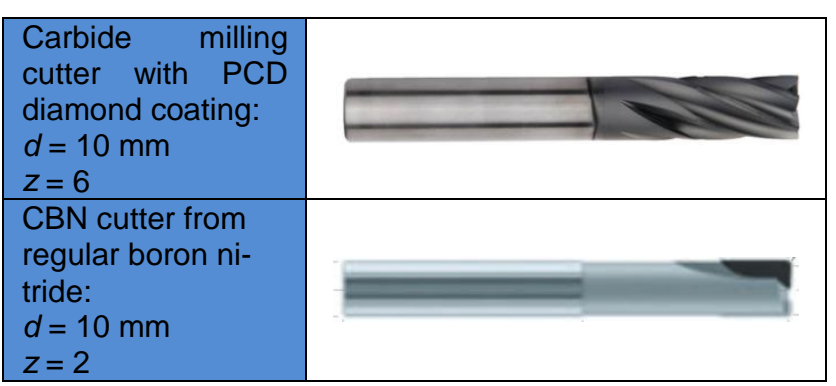

During the tests, the cutting depth values $a_{p}$ and the cutting width $a_{\mathrm{e}}$ were constant and amounted to: $a_{\mathrm{p}}=10$ $\mathrm{mm}, a_{\mathrm{e}}=0.3 \mathrm{~mm}$. Measurements of vibrations and forces were made in three directions: feed $\left(F_{\mathrm{f}}, A_{\mathrm{f}}\right)$, feed normal $\left(F_{\mathrm{fN}}\right.$,
$\left.A_{\mathrm{fN}}\right)$ and resistant $\left(F_{\mathrm{p}}, A_{\mathrm{p}}\right)$. From the received forces and vibrations, statistical measures were determined, such as mean square root RMS values (root mean square). The analysis was made as a function of time and frequency. The analysis mainly concerned the impact of cutting speed and feed on the level of amplitudes of the vibrations and forces.

\section{Test results}

- Graphs as a function of time. The results were presented in the form of graphs of forces and vibrations as a function of time.

Fig. 2 shows a graph of the $F_{\mathrm{fN}}$ component with a selected time interval corresponding to one tool revolution. In turn, fig. 3 shows the graph of the course of force components $F_{\mathrm{p}}$ at different cutting speeds for the PCD cutter. Amplitudes of the component forces were read in each interval in time for a given cutting speed.

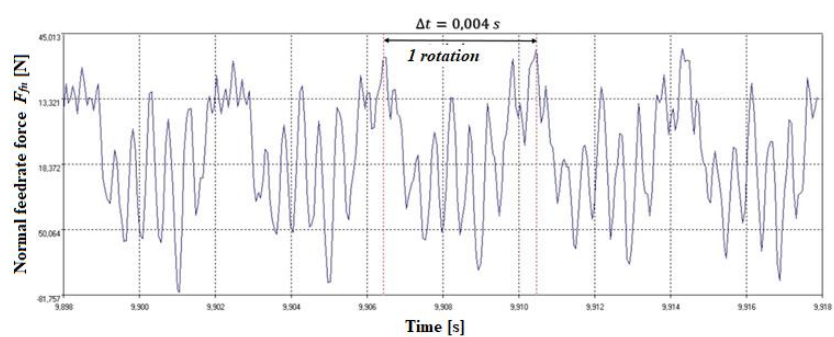

Fig. 2. Plot of normal federate force $F_{\mathrm{fN}}$ in a narrowed range of time at feed $f=0.01 \mathrm{~mm} / \mathrm{rev}$

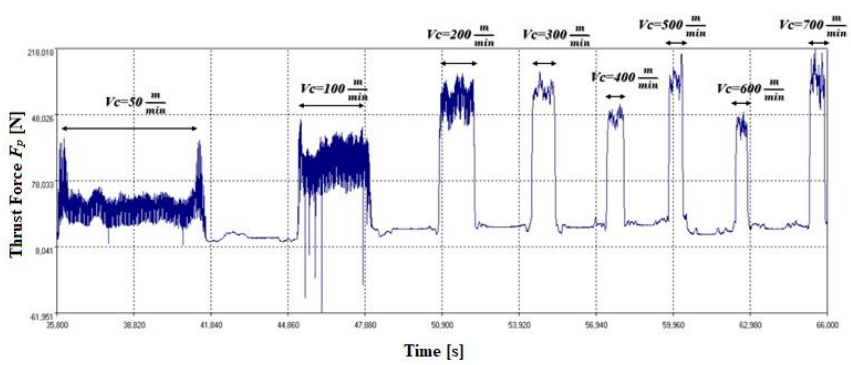

Fig. 3. Graph of thrust force component $F_{\mathrm{p}}$ for PCD cutter at different cutting speeds (fixed parameters: $a_{\mathrm{e}}=0.3 \mathrm{~mm}, a_{\mathrm{p}}=10$ $\mathrm{mm}, f=0.1 \mathrm{~mm} / \mathrm{rev}, f_{z}=0.02 \mathrm{~mm} /$ tooth)

- Mean square values of forces and vibrations. The received values of forces and vibrations are presented in figs. 4-9.

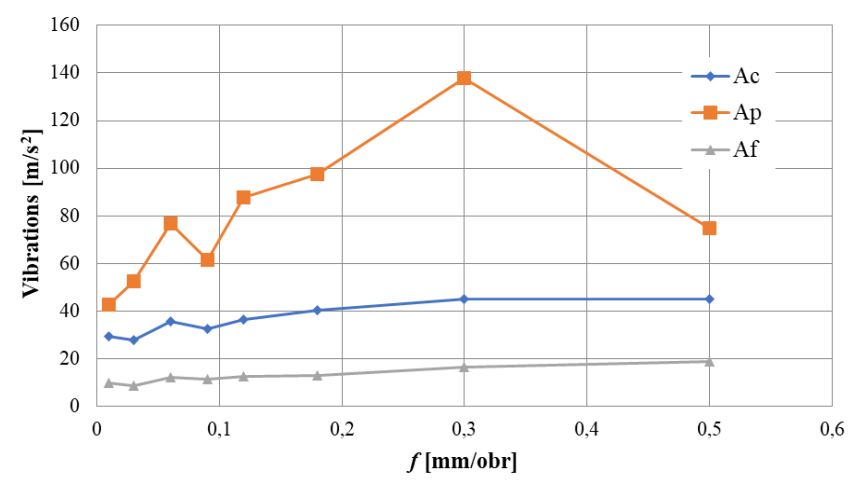

Fig. 4. Diagram of mean square values for PCD cutter at constant cutting speed 


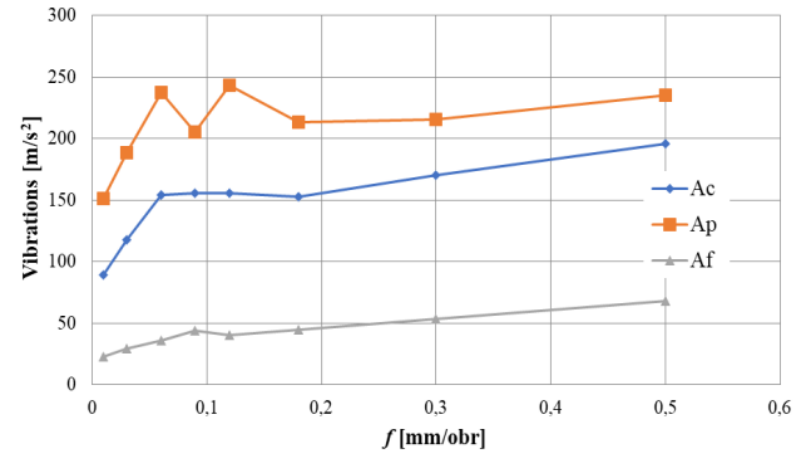

Fig. 5. Diagram of mean root vibration values for a CBN cutter at a constant cutting speed

It can be seen that the smallest vibration amplitude values occur when machining with a PCD diamond-coated cutter. The same applies to the CBN regular nitride cutter. However, fig. 5 shows that along with the increase in feed, the vibration values reach much higher amplitudes than in the PCD cutter. The largest amplitudes are for vibrations in the thrust direction. The smallest values, in the same way as for the PCD cutter, occur in the direction $Y$ - feed $A_{\mathrm{f}}$.

As with variable feed, also at variable cutting speeds (fig. 6 and fig. 7), the vibration amplitude is lower for the PCD cutter as compared to the CBN cutter. In the case of a PCD cutter for $v_{c}=300 \mathrm{~m} / \mathrm{min}$, self-excited vibrations appeared, which resulted in a several-fold increase in amplitudes.

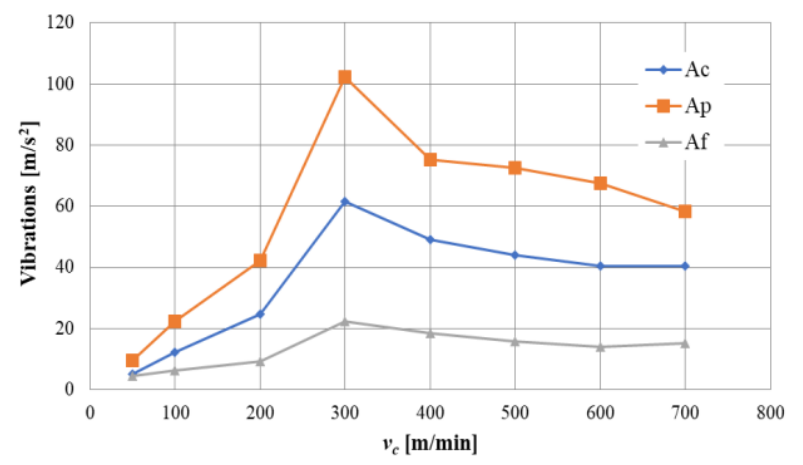

Fig. 6. Graph of mean square values for PCD cutter with constant feed per revolution

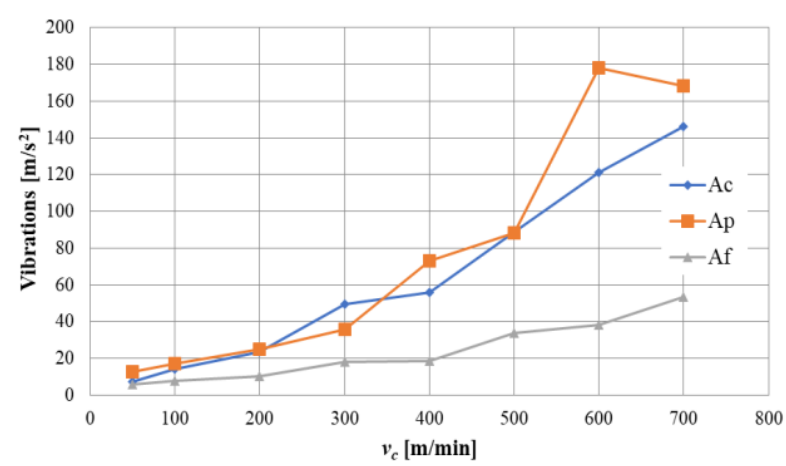

Fig. 7. Graph of mean square vibration values for a CBN cutter with constant feed per revolution

Fig. 8 and 9 show examples of average-square values for components of total force. Together with the increase in the feed per revolution, the value of the forces monotonically increases, which is in line with the theoretical models. In addition, the values of the total force components are significantly higher compared to the results for a PCD cutter.

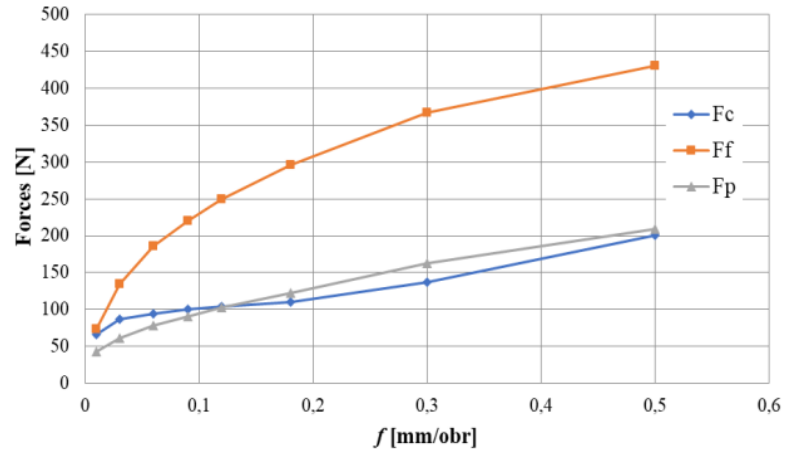

Fig. 8. Graph of the mean square values of forces for a CBN cutter with constant feed per revolution

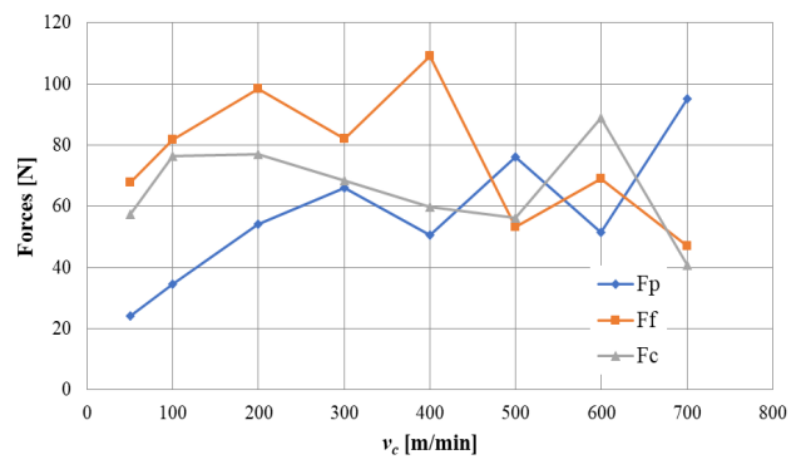

Fig. 9. Graph of the mean square values of forces for a CBN cutter at a constant cutting speed

At the change of cutting speed (fig. 9), non-monotonic changes of amplitudes for all components were noted. The same trend occurred for the PCD cutter, i.e. the nonmonotonic waveforms and amplitude values were much smaller than for the CBN.

- Frequency analysis. Fig. 10 shows the amplitudefrequency characteristics of $F_{\mathrm{fN}}$ force for PCD cutters at constant cutting speed and load. The amplitudes of individual bands are several times smaller for PCD cutter compared to CBN cutter, as confirmed by the prior analysis of RMS values in the time domain. In turn the nature of the spectrum is closely correlated with the two basic frequencies:

- $f_{0}$ - the frequency associated with the speed $n, f_{0}=n / 60$,

- $f_{\mathrm{oz}}$ - frequency of the milling process $f_{\mathrm{oz}}=f_{0} \times z$.

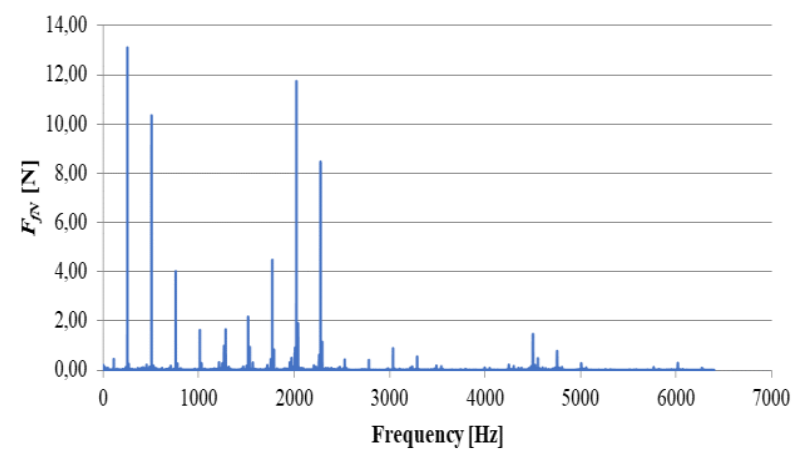

Fig. 10. $F_{\text {fN }}$ component for PCD cutter at constant cutting speed and feed $f=0.01 \mathrm{~mm} / \mathrm{rev}$

In all the analyzed power spectra and vibration accelerations, the largest amplitudes occur for the signal components $f_{\mathrm{o}}$ and $f_{\mathrm{oz}}$ and their harmonic frequencies, which indicates the determination of the basic kinematics of the milling process. 


\section{Conclusions}

- In all amplitude parameters considered vibrations for the feed direction $A_{\mathrm{f}}$ are the smallest.

- Milling with a CBN cutter gives higher vibration amplitudes compared to a PCD cutter.

- Increase in the cutting speed caused a slight decrease in the values of forces $F_{\mathrm{f}}$ and $F_{\mathrm{fN}}$. In the case of $F_{\mathrm{p}}$, a slight increase in force was observed with increasing cutting speed.

- When changing the feed while maintaining a constant speed, a significant effect on the increase of all components of the total force is visible.

- Frequency analysis showed that the waveforms (signals) of the components of the total force and the components of the vibration accelerations are determined mainly by the kinematics of the milling process.

\section{REFERENCES}

1. Bieniaś J., Walczak M., Surowska B., Sobczak J. "Microstructure and corrosion behavior of aluminium Fly ash composites". Journal of Optoelektronics and Advanced Materials. 5, 2 (2003): pp. 493-502.

2. Karolczak P., Kowalski M. „Możliwości kształtowania toczeniem metalowych materiałów kompozytowych o zwiększonej zawartości wzmocnienia". G. Wróbel (red.). Polimery i kompozyty konstrukcyjne. Cieszyn: Wydawnictwo Logos Press, 2010, pp. 150-157.

3. Kishawy H.A., Kannan S., Balazinski M. "An energy based analytical force model for orthogonal cutting of metal matrix composites". CIRP Annals. 53, 1 (2004): pp. 91-94.

4. Rashid A., Nicolescu C.M. "Active vibration control in palletised workholding system for milling". International Journal of Machine Tools \& Manufacture. 46 (2006): pp. 1626-1636.

5. Sobczak J. "Metalowe materiały kompozytowe”. KrakówWarszawa: Wyd. Instytutu Odlewnictwa i Instytutu Transportu Samochodowego (2002).

6. Teti R. "Machining of composite materials". CIRP Annals. 51, 2 (2002): pp. 611-634.

7. Walczak M., Pieniak D., Bieniaś J. „Zużycie i struktura powierzchni aluminiowych kompozytów zbrojonych czasteczkami SiC w warunkach tarcia technicznie suchego". Autobusy: Technika, Eksploatacja, Systemy Transportowe. 13, 7-8 (2012): pp. 167-173.

8. Wojciechowski S. "The estimation of cutting forces and specific force coefficients during finishing ball end milling of inclined surfaces". International Journal of Machine Tools \& Manufacture. 89 (2015): pp. 110-123.

9. Vencla A., Bobicb I., Arosteguic S., Bobicd B., Marinkovica A., Babice M. "Structural, mechanical and tribological properties of A356 aluminium alloy reinforced with $\mathrm{Al}_{2} \mathrm{O}_{3}, \mathrm{SiC}$ and $\mathrm{SiC}$ +graphite particles". Journal of Alloys and Compounds. 506, 2 (2010): pp. 631-639.

Translation of scientific articles, their computer composition and publishing them on the website www.mechanik.media.pl by original articles in Polish is a task financed from the funds of the Ministry of Science and Higher Education designated for dissemination of science.

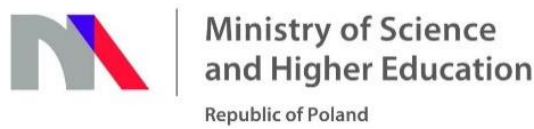

